Pastor, Peter. "A New Historical Myth from Hungary: The Legend of Colonel Ferenc Koszorús as the Wartime Savior of the Jews of Budapest. Review Article of Jeszenszky, Géza, ed. July 1944: Deportation of the Jews of Budapest Foiled. Reno, Nevada: Helena History Press, 2018, pp. 317. Distributed by CEU Press." Hungarian Cultural Studies. e-Journal of the American Hungarian Educators Association, Volume 12 (2019) DOI: 10.5195/ahea.2019.355

\title{
A New Historical Myth from Hungary: The Legend of Colonel Ferenc Koszorús as the Wartime Savior of the Jews of Budapest. Review Article of Jeszenszky, Géza, ed. July 1944: Deportation of the Jews of Budapest Foiled. Reno, Nevada: Helena History Press, 2018, pp. 317. Distributed by CEU Press.
}

\section{Peter Pastor}

\begin{abstract}
This book is a compilation of essays by authors who were previously published elsewhere. Its main focus is on Ferenc Koszorús, a wartime colonel of the Hungarian army fighting as an ally of Germany who ostensibly was responsible for saving the Jews of Budapest with the so-called Koszorús Action during the German occupation of Hungary. Some of the articles also examine the roles of Regent Miklós Horthy and the Hungarian government in the destruction of close to one half million of its Jewish citizens, mostly in German death camps. The reviewer marshals facts, documentation, and works by prominent historians to demonstrate that Koszorús had little to do with the survival of the Budapest Jews in July 1944. The myth of Koszorús as a wartime champion of the Jews was invented by the colonel himself in his postwar memoirs. In the volume, the editor Géza Jeszenszky points out that most non-Jewish Hungarians were either active supporters of the deportations or were passive bystanders. It may be this sad fact that prompted him to mythologize and create a hero who allegedly saved the life of three hundred-thousand Jews.
\end{abstract}

Keywords: Hungary, World War II, Regent Miklós Horthy, Colonel Ferenc Koszorús, Hungarian Holocaust, Deportations, Budapest, German occupation of Hungary, Edmund Veesenmayer, László Baky

Biography: Peter Pastor is Professor Emeritus of history at Montclair State University, New Jersey. His special interest is the history of diplomatic and military relations between Hungary and Russia/USSR. He is the author of numerous articles, a monograph, and editor or coeditor of several books. pastorp@montclair.edu

The recently deceased doyen of the history of the Hungarian Holocaust, Randolph L. Braham, observed that in Hungary, "The campaign for the rehabilitation of the Horthy era, coupled with the drive to falsify the history of the Holocaust, gained momentum during Prime Minister Orbán's second term of office and continued unabatedly during his third" (Braham 2016: 286).The anthology under review, edited by the historian Géza Jeszenszky, Orbán’s 
Pastor, Peter. "A New Historical Myth from Hungary: The Legend of Colonel Ferenc Koszorús as the Wartime Savior of the Jews of Budapest. Review Article of Jeszenszky, Géza, ed. July 1944: Deportation of the Jews of Budapest Foiled. Reno, Nevada: Helena History Press, 2018, pp. 317. Distributed by CEU Press." Hungarian Cultural Studies. e-Journal of the American Hungarian Educators Association, Volume 12 (2019) DOI: 10.5195/ahea.2019.355

ambassador to the United States from 1998-2002, and to Norway from 2011-2014, attempts to advance the rehabilitation campaign.

The essays in this book have already been published elsewhere in Hungary and/or in the United States. The anthology's main goal, as its title indicates, is to acquaint the readers with Ferenc Koszorús, a wartime colonel of the Hungarian army fighting as an ally of Germany, and promote him as a man who allegedly saved the Jews of Budapest from deportation during the German occupation of Hungary. A number of articles focus on Koszorús, while others are intended to provide historical background only. To one degree or another, the latter attempt to mitigate the responsibility of Regent Miklós Horthy and the Hungarian government in the destruction of close to one-half million Jewish citizens, mostly in German death camps. The effort to refashion Colonel Koszorús into a Hungarian Raoul Wallenberg is contradicted by facts, documents and works by prominent Holocaust historians such as Krisztián Ungváry (Ungváry 2016: 145-146), László Karsai (Karsai 2012: 53-56), Judit Molnár (2014), László Csősz (2013: 42), Zoltán Vági and Gábor Kádár (2013: 137) all of whom demonstrate that Koszorús had little to do with the survival of Budapest's Jews in July 1944. Overall, the editor has selected articles some of which are tangential or dated, and some whose authority and/or scholarship is questionable. In his own contributions, Jeszenszky altered a key date in an attempt to refashion the motive for events, omitted essential parts of primary sources that contradict purported claims, do not represent accurately findings of a noted scholar and neglected to take existing documents or alternate views into account.

The myth of Koszorús that grew out of the so-called Koszorús Action appears to have been launched by the colonel himself. It was written and presented before an audience in Cleveland in 1961 and published as part of his memoirs in Hungarian in New Jersey in 1987. Karsai claims that it is the son of Koszorús, Ferenc Koszorús Jr., who "following long years of tireless work spread the Koszorús legend which by today has swollen to an amazing size" $[A z$ ifj. Koszorús által hosszú évek lankadatlan munkájával terjesztett Koszorús-legendárium mára már egészen elképesztö méretüvé duzzadt] (Karsai 2014).

Jeszenszky's compilation opens with a five-page Foreword by the journalist, Charles Fenyvesi, entitled "The Long Silence of a Heroic Hungarian." The title refers to the author's claim that Koszorús kept his alleged heroism to himself. Previously Fenyvesi provided a blurb to the back cover of a Hungarian book of essays, Páncélosokkal az életért: "KoszorúsFerenc a holokauszt höse" ['With Tanks for Life: "FerencKoszorús the Hero of the Holocaust"'] (Hantó and Szekér 2015). In that book, Fenyvesi blamed Hitler, Stalin and their respective students for rewriting history and viewed the publication of the book about Koszorús as undoing the rewrite. His foreword concludes that "time has come to recognize Colonel Koszorús as a rare hero of the anti-Nazi resistance" (5). From the brief biography of Koszorús that Fenyvesi offers, however, there is no indication that Koszorús was in the anti-Nazi resistance. Fenyvesi describes that, "In April 1945, the Wehrmacht retreated back to the Reich, along with much of the Hungarian officer corps, Koszorús ended his military career by surrendering to the Americans" (3). This means that, contrary to Fenyvesi's claim, Koszorús did not remain loyal to his oath of allegiance to Horthy (5) since in order to stay in military service, he took an oath of allegiance to the fascist Arrow Cross leader, Ferenc Szálasi, who became the dictator of Hungary on October 16, 1944 following a German-backed coup. In one of his writings, Koszorús himself rationalized why he 
Pastor, Peter. "A New Historical Myth from Hungary: The Legend of Colonel Ferenc Koszorús as the Wartime Savior of the Jews of Budapest. Review Article of Jeszenszky, Géza, ed. July 1944: Deportation of the Jews of Budapest Foiled. Reno, Nevada: Helena History Press, 2018, pp. 317. Distributed by CEU Press." Hungarian Cultural Studies. e-Journal of the American Hungarian Educators Association, Volume 12 (2019) DOI: 10.5195/ahea.2019.355

sided with the Nazi puppet Szálasi: "German brute force placed Szálasi in the position of head of state when the gates of the country were battered by Bolshevism. In this situation it would have been a crime to further intensify the Hungarian state's collapse into ignominy by having the officer corps, by this time past redemption, turn against the unlawful political system, and speed up disintegration" [a német eröszak a magyar államföi helyre Szálasit ültette, az ország kapuit a bolsevizmus döngette, így ebben a helyzetben a magyar állam gyalázatba fulladt szétesését bün lett volna tovább azzal fokozni, hogy a tisztikar immáron a jóvátehetetlenért, a törvénytelen államrend ellen fordulva, fokozza a szétesést] (Koszorús 1987: 295). These lines, as does most of his memoir, indicate that Koszorús was hardly a model anti-fascist resistor. In fact, his action and writings indicate that he was a collaborator.

The Foreword is followed by Jeszenszky's introduction and by nine chapters, each a reprint, or slightly revised work, from Tom Lantos, György Ránki, Géza Jeszenszky, Deborah Cornelius, István Deák, Tamás Stark, Attila Bonhardt, Susan Berger and Vadim Birstein coauthors, and lastly from Ferenc Koszorús Jr. The two overarching articles, i.e. the Introduction and a stand-alone chapter were written by Jeszenszky while the rest seem to serve only to reinforce those articles. This justifies a more detailed examination of his works in this review. The Appendix contains sixteen selected documents from the German Foreign Office. The basis for their selection is unexplained as the first is dated October 6, 1942, and the last, July 17, 1944. The documents seem to put the activities of the Horthy regime in a favorable light at the expense of the Germans.

Jeszenszky's Introduction, part of which previously appeared in a journal (Jeszenszky 2018), begins with a background statement about the German occupation that started on March 19, 1944. "Following that, in less than three months half a million of Hungary's Jews were deported" and killed in German death camps. Aside for the fact that the destruction of Hungarian Jewry took a little more than a month-and-a-half as deportations started on May 15 and were suspended by Horthy on July 6, Jeszenszky is correct that ghettoization and deportation was carried out "by their fellow Hungarians" (emphasis by Jeszenszky). Immediately afterward, however, Jeszenszky introduces a mitigating circumstance, a technique he repeatedly uses when Hungarian or, more specifically, Horthy's culpability is mentioned. In this first case he writes, "Of course such a crime would have never taken place but for the presence of a quarter million German soldiers, who initiated and backed the deportations" (1). Jeszenszky overstates the number of occupying German forces; in March 1944, they numbered less than half the number at 120,000 and by the start of the deportations, the troops' strength had fallen to 57,300. By June, the occupiers numbered 46,500; of these 26,000 were ethnic Germans from Hungary (Ungváry 2016: 125). The regular German troops had been stationed there to keep Hungary in the alliance and were not involved with the deportations. In fact, with only about sixty-five men, the Eichmann commando (Ungváry 2016: 124) who were in an advisory position to the Hungarian authorities could not have accomplished the deportations without the active assistance of an estimated 200,000 Hungarians, gendarmes, policemen, and administrators. From the very beginning the Hungarian authorities insisted that the deportations be expedited; it is estimated that had it been without this prompting, 170,000 to 180,000 would have met their fate in the death camps instead of the 437, 000 (Csepeli and Vági 2011). 
Pastor, Peter. "A New Historical Myth from Hungary: The Legend of Colonel Ferenc Koszorús as the Wartime Savior of the Jews of Budapest. Review Article of Jeszenszky, Géza, ed. July 1944: Deportation of the Jews of Budapest Foiled. Reno, Nevada: Helena History Press, 2018, pp. 317. Distributed by CEU Press." Hungarian Cultural Studies. e-Journal of the American Hungarian Educators Association, Volume 12 (2019) DOI: 10.5195/ahea.2019.355

Jeszenszky returns to the question of responsibility for the Hungarian Holocaust eight pages later when he asks: "Does it fall exclusively on Germany, which occupied its nominal ally, and under the direction of Adolf Eichmann initiated the 'final solution of the Jewish Problem'....Or is the guilt more than shared by the collaborationist Hungarian government and its civil servants...?"(8). That Jeszenszky calls Hungary a nominal ally in WW II is odd, given the fact that Hungary joined Germany in the Tripartite Pact as an ally in 1940, then joined the Third Reich in attacks on Yugoslavia and the USSR in 1941. The reason he does this may relate to his attempt yet again to minimize Hungary's war guilt. Responding to his own rhetorical question at this point Jeszenszky correctly finds Adolf Eichmann responsible for the deportations and not the over-counted "250,000" occupiers, and concludes that, "Both Germans and Hungarians bear responsibility for the Holocaust in Hungary" (14). On the following page, however, he mitigates again by equating the passive mass reaction to the deportations with the communist persecution of "hundreds of thousands of innocents" (15). It is for making similar perverse parallels that Braham accused Jeszenszky of being a history-cleanser (Braham 2016: 280 and n.39).

Following his conclusion that the Hungarian Holocaust was a joint enterprise, Jeszenszky touches on Regent Miklós Horthy's responsibility without giving a straight answer: "[he] passively watched the deportations, allegedly not knowing what was in store for his fellowcitizens. At the end of June 1944, however, seeing the coming defeat of Germany...he managed to halt the process just before the deportations from Budapest were to start" (8). In his memoirs Horthy claimed he was powerless to defend the Jews outside of Budapest and that until early July 1944 he did not know about the functioning of the death camps (Horthy 1990: 290-291).In fact, as early as 1943 Horthy knew about the fate of deported Jews in Europe (Turbucz 2011: 201). This is clearly indicated in a document that was published from Horthy's papers (Szinai and Szücs: 398). Jeszenszky must know these facts, yet he repeats Horthy's claim (27). Jeszenszky's intention to rehabilitate is also shown by judging Horthy's passivity as resistance to the Germans (24).

Jeszenszky is also wrong in claiming that Horthy halted the deportations at the end of June 1944. He backdates Horthy's July 6 suspension order for the deportations to the Crown Council meeting of June 26 (20) to make sense out of the Baky coup and the accompanying Koszorús Action that allegedly saved Jewish lives. According to Jeszenszky:

By July 6, gendarmerie units that were loyal to the pro-Nazi puppet government and ready to carry out the deportation of the close to 300,000 Jewish Hungarians living in Budapest were brought to Budapest....There were rumors that the pro-Nazi and rabidly anti-Semitic under-secretary of the interior, László Baky, was in fact planning a coup to remove Horthy and continue the deportations, Colonel Ferenc Koszorús volunteered to intervene, and having received the command from Horthy, entered Budapest with his $1^{\text {st }}$ Armored Corps, ordered the withdrawal of the gendarmerie, and thus foiled both the planned coup (if that really had been planned) and the continuation of the deportations (8). 
Pastor, Peter. "A New Historical Myth from Hungary: The Legend of Colonel Ferenc Koszorús as the Wartime Savior of the Jews of Budapest. Review Article of Jeszenszky, Géza, ed. July 1944: Deportation of the Jews of Budapest Foiled. Reno, Nevada: Helena History Press, 2018, pp. 317. Distributed by CEU Press." Hungarian Cultural Studies. e-Journal of the American Hungarian Educators Association, Volume 12 (2019) DOI: 10.5195/ahea.2019.355

The description indicates that Horthy was not acting on the basis of solid military intelligence, but rather on unsubstantiated rumors. Moreover, if Horthy halted the deportations on July 6, then a coup planned for the same day, in opposition to the regent's order, could not have taken place. It is for this reason that Jeszenszky backdates Horthy's order. Jeszenszky seems to be aware that he is not reporting the correct chronology and in parentheses suggests that perhaps the coup was about to take place on the spur of the moment. Yet by its very nature a coup has to be planned. Horthy's suspicion, however, was not connected to his halting of the deportations. It was the gathering of a large number of gendarmes that terrified him as he came to suspect that they, under the guise of performing the deportations, intended to overthrow him (Koszorús 1987: 57). For this reason, Holocaust historians believe that "the plan to deport the Budapest Jews fell through primarily because of Horthy's concern for his own position" (Vági, Csősz and Kádár, 2013: 137).

Jeszenszky is also incorrect in asserting that the gendarmerie units were loyal to the "pro-Nazi government." In their oath, the gendarmes pledged their loyalty to the Supreme Warlord Miklós Horthy. Holocaust historians such as László Karsai, and Horthy's latest biographer (Turbucz 2011: 203) claim that in fact it was upon Horthy's command that the gendarmes, who remained loyal to the regent, left the city. As Karsai writes, "By the time Koszorús and his steel chariots rumbled into Budapest, there were no gendarmes there" [Mire Koszorús és páncélosai bedübörögtek Budapestre, ott már nem voltak csendörök] (Karsai 2014b).

Karsai documents that the Hungarian Fascist Party, the Arrow Cross, which was also implicated in Koszorús's memoirs, had nothing to do with the so-called "coup" and makes a convincing case that a coup against Horthy without the knowledge and approval of Berlin would have been impossible; to date no German archival evidence has surfaced to imply that such a conspiracy existed. (Karsai 2012: 53). In fact, a July 6 report from German Plenipotentiary Edmund Veesenmayer to Foreign Minister Joachim von Ribbentrop, that is included in the Appendix, may serve as proof that contrary to claims, the Germans were not involved in Horthy's made-up coup. Veesenmayer reported the following:

In the meantime, tonight I received messages from two sides that say that the Regent is seriously expecting a coup by Szalasi or Baky. Supposedly, Hungarian officers were on alert; however, neither the higher-level SS- and police leader [Polizeiführer] nor the commanding general of the German Wehrmacht in Hungary was able to confirm any details....Personally, I currently see no serious starting point [Ansatzpunkt] for the possibility of a coup (292).

Veesenmayer's message undermines the essence of every essay (Jeszenszky, Deák, Cornelius, Bonhardt, and Frank Koszorús Jr.) in this volume that contains references to the Baky coup as an actual conspiracy, not to mention the claim that the last minute armed intervention by Koszorús and his men saved the day.

In his Introduction Jeszenszky later states that his claim that Horthy halted the deportations on June 26, 1944, is backed by most historians: "Practically all professional historians agree that Horthy's call in the Crown Council of 26 June not to proceed with the deportation of the Jews saved those living (or hiding) in the capital" (20). But not all historians 
Pastor, Peter. "A New Historical Myth from Hungary: The Legend of Colonel Ferenc Koszorús as the Wartime Savior of the Jews of Budapest. Review Article of Jeszenszky, Géza, ed. July 1944: Deportation of the Jews of Budapest Foiled. Reno, Nevada: Helena History Press, 2018, pp. 317. Distributed by CEU Press." Hungarian Cultural Studies. e-Journal of the American Hungarian Educators Association, Volume 12 (2019) DOI: 10.5195/ahea.2019.355

agree; in fact, most do not because the primary source, Horthy's available draft of the speech, contradicts Jeszenszky's claim (E. Karsai 2017: 29). Jeszenszky should have included this crucial document in the Appendix, although that evidence would have demolished his argument.

Jeszenszky identifies the prominent historian, the late György Ránki, as one of the "many" who agree and cites as his source an article in a collection of Ránki essays. Ránki, however, did not "agree" that Horthy stopped the deportations on June 26. In another article from the same book, Ránki made this clear: "Horthy did not decisively take position on the issue of the deportations....A few days later, however, on July 6 the regent halted the deportations" [Horthy nem foglalt határozottan állást a deportálások ügyében ....Néhány nappal késöbb, július 6-án a kormányzó leállította a deportálást] (Ránki 1988a: 223). When Jeszenszky quotes the following statement from Ránki that "It is an irony of fate that in saving the Jews of Budapest decisive credit belongs to Horthy" (20), Ránki is referring to July 6, and not to June 26. Historians can agree with the July 6 date, and see why Ránki finds Horthy's step ironic. It is ironic because "Horthy and his regime are heavily responsible" [Horthy és rendszere súlyosan felelös](Ránki 1988b: 207). Heavily responsible for the tragedy that ended in the liquidation of Jews in Hungary.

In his attempt to mitigate Horthy's responsibility Jeszenszky's writes the next explanation:

On June 21 Veesenmayer informed Ribbentrop of Horthy's 'secret' letter to Sztójay blaming the harsh treatment of the Jews....It is true that the letter did not order a stop to the deportations, and Horthy continued to show sympathy only to the well-educated, 'useful' professional Jews, and wanted to protect those who converted to Christianity, but nevertheless the intention was to radically curtail 'the final solution' (25-26).

This observation is disturbing on many levels. Most importantly, it implies that Jeszenszky is not horrified by the fact that Horthy freely acquiesced to the deportation of the overwhelming majority of Hungarian Jews who were neither converts, nor well-educated. Jeszenszky praises Horthy's good intention instead of criticizing him for not stopping the deportations earlier (Gellért and Turbucz 2012: 10). Lastly, Jeszenszky omitted from the Appendix the Horthy letter, available in his published papers; in it the Regent compared the German treatment of the Jews favorably to the Hungarians': "in such a brutal, and at times inhumane manner that not even the Germans carried out such actions" ['olyan brutális, söt olykor embertelen módon, ahogyan maguknál a németeknél sem történtek az intézkedések'] (Szinai and Szücs: 451). This meant that if the Hungarians were less cruel than the Germans, the deportations could be carried out. While quoting from Veesenmayer's report, Jeszenszky skips over the plenipotentiary's dismissive comment that Horthy's protest "... serves as his alibi towards the English and the Americans in case the war would end badly" [...inkább alibi az angolok és az amerikaiak felé arra az esetre, ha a háború rosszúl végzödne] (Ránki1968: 870). Since Jeszenszky's argument is based on an important Wilhelmstrasse document, he should have included this one in the Appendix as well.

Jeszenszky attributes the rise of anti-Semitism in Hungary to the short-lived Soviet Republic of 1919, although anti-Semitism existed well before that date (Bihari 2018: 2, Kovács 2012: 44, Karady 2016: 56-57). Jeszenszky writes, “Anti-Semitic notions and tendencies were 
Pastor, Peter. "A New Historical Myth from Hungary: The Legend of Colonel Ferenc Koszorús as the Wartime Savior of the Jews of Budapest. Review Article of Jeszenszky, Géza, ed. July 1944: Deportation of the Jews of Budapest Foiled. Reno, Nevada: Helena History Press, 2018, pp. 317. Distributed by CEU Press." Hungarian Cultural Studies. e-Journal of the American Hungarian Educators Association, Volume 12 (2019) DOI: 10.5195/ahea.2019.355

present in Hungary at least since 1919, the Hungarian Soviet Republic, where most of the leaders came from Jewish families and due to their blind faith in the communist utopia they employed terror against those whom they considered dangerous opponents, including Jewish capitalists" (18). Jeszenszky thus perpetuates the right-wing myth of Judeo-Bolshevism, which identifies the Soviet Republic as a Jewish revolution (Csunderlik 2019: 175-176) despite the fact that out of 500,000 Hungarian Jews only about 3,000 took an active role in it (Kovács 2012: 49). It was this myth that Prime Minister Döme Sztójay used to justify the deportations. On July 6, 1944, on the day when Horthy ordered a halt to deportations, Sztójay told the papal nuncio, who had expressed concern about the fate of the Hungarian Jews, that "The racially pure Jews are generally the representatives of destruction, as in 1918 [sic] they were destroying the most and were the allies of the Bolsheviks" ['a fajzsidók általában a destrukció képviselöi, amint 1918ban is ök destruáltak leginkább és voltak a bolsevisták szövetségesei’] (E. Karsai 2017: 97).

Jeszenszky identifies Hungarian racist anti-Semitism in the 1930s as an echo of Hitler's ideology, thereby keeping silent about Act 25 of September 26, 1920, the onerous Numerus Clausus law, which limited the number of the Jewish students at universities. It was the signpost for the counterrevolution's racist anti-Semitism well before Hitler became the chancellor of Germany (Csepeli 2016: 153 and Kovács2012: 54-55). For Jeszenszky, the issue of anti-Jewish laws starts rather with 1938 when "several laws were passed by the Hungarian Parliament and decrees issued restricting the rights of Jews" (12). In fact, not several, but twenty-one anti-Jewish laws were passed between 1938 and 1944 and the number of decrees amounted to more than 267 (Karsai 2005: 141, 143). Jeszenszky declares that, "despite those most deplorable and disgraceful laws, the life and liberty of those 800,000 Hungarian citizens of Jewish background were not in danger until the occupation by Germany" (12). His characterization does not do justice to the situation since these laws were not only degrading, but also deprived the Jews of their livelihoods, professional careers, property and completely excluded them from economic and cultural life. Act 15 of 1941 prohibited intermarriage and called for severe prison sentences for the contravention of the law (Vértes 1997: 149-152). Under these circumstances, arguing that the liberty of Jews was not in danger is tortuous.

While Horthy at first resisted Hitler's pressure to deport the Jews, he did so believing that they were still needed for economic reasons. On May 7, 1943, Horthy wrote to Hitler: "Further actions for the gradual exclusion of the Jews are in the works and as soon as the conditions will be right for their deportations, we will carry that out too" [A zsidók fokozatos kikapcsolására vonatkozó további intézkedések folyamatban vannak, s amint meglesznek teremtve elszállitásuk feltételei, ezt végre is fogjuk hajtani] (Szinai and Szücs 1972: 392). The series of anti-Jewish laws and decrees were proof of the gradual exclusion of the Jews and Horthy's words have to be taken at their face value. The life of Jews was in danger, and their death sentence was already expressed in words well before the German occupation.

Jeszenszky also tries to mitigate the Hungarian responsibility for the Holocaust by magnifying parliamentary opposition to the Jewish laws (16). His claim is misleading on many counts as the source for his footnote is a Smallholder Party memorandum. The party was one of the opposition parties in Parliament that also included the anti-Semitic Arrow Cross Party, hardly an opponent of anti-Jewish laws. The memorandum was submitted not in the fall, but in the summer of 1943, and not to the House of Representatives as a bill, but to the Prime Minister 
Pastor, Peter. "A New Historical Myth from Hungary: The Legend of Colonel Ferenc Koszorús as the Wartime Savior of the Jews of Budapest. Review Article of Jeszenszky, Géza, ed. July 1944: Deportation of the Jews of Budapest Foiled. Reno, Nevada: Helena History Press, 2018, pp. 317. Distributed by CEU Press." Hungarian Cultural Studies. e-Journal of the American Hungarian Educators Association, Volume 12 (2019) DOI: 10.5195/ahea.2019.355

(Török 2018: 2) for his consideration. It is significant to point out that in the House of Representatives there were only fourteen Smallholders out of 367 members. The overwhelming majority represented the government party (Püski 2015: 480) and it supported the anti-Jewish laws.

Civilian help to hide Jews is also exaggerated when Jeszenszky mentions as proof that the Israeli Yad Vashem Institute honored close to a thousand Hungarians as "Righteous Among the Nations." It is noteworthy, however, that Jeszenszky's great man in history, Colonel Koszorús, who allegedly saved 300,000 Jews, is not among those who were recognized as such.

Jeszenszky closes his introduction with the subheading, "Was Horthy a War Criminal?" He informs his readers that at the Nuremberg war crime trials the Americans did not want to try him and Stalin did not wish to make him into a martyr. Jeszenszky seems to absolve Horthy from war guilt as he saved Budapest's Jews, but as Braham noted, "While this is basically true, history-cleansers... fail to acknowledge Horthy's own responsibility for the liquidation of the provincial Jewish communities" (Braham 2016: 289).

In the Introduction, Jeszenszky states that his volume's "purpose is only to show what really happened in those crucial days in early July" (9). My review indicates that Jeszenszky's Introduction goes beyond that. He reexamines Hungary's and Regent Horthy's role in the Holocaust and does not focus only on the immediate precedents and aftermath of the Koszorús Action. As an Introduction Jeszensky's article lacks both a synthesis of the selected articles and an overview summarizing their commonality; it also lacks an explanation for why he chose articles that are not scholarly or do not touch upon the Koszorús Action. While he mentions interpretations of two schools of Holocaust historians, his description misrepresents (17) the interpretation of László Karsai (A. Kovács 2016: 10). In his effort to rehabilitate the Horthy regime's past, Jeszenszky fails to include a single scholarly article in the anthology that would contradict the positions he takes.

The anthology's first chapter, "Ferenc Koszorús a Hero of the Hungarian Holocaust," was written by US Representative, Tom Lantos, a Holocaust survivor who was saved by Wallenberg. The exaltation of Koszorús in the book reaches a crescendo with this three-page laudation Lantos entered in the 1994 Congressional Record. Not trained as a historian, Lantos provides a brief and imprecise history of the events and cites Koszorús as one of the few who had stood up to Nazi occupation and to the Gestapo-supported coup and "took the initiative to resist" (34). The criticisms in this review indicate that Lantos's understanding of history is far off the mark.

When reading the Koszorús memoirs, one wonders just how averse to the Nazis Koszorús really was. In his essay written in 1971, Koszorús claims that after his actions in Budapest he was in fear of the Gestapo. Yet by mid-September, he had taken part as a commander in a tank battle against the Red Army and brags that near Arad he had stopped the Soviet advance for six days (Koszorús 1987: 330). Thus, two months after his alleged saving of the Jews of Budapest, he gave no consideration to the fact that by resisting he was lengthening the lost war and thereby extending the suffering of the Jews of Budapest. This sad irony did not occur to him even twenty-five years after the conflict, when he put his memories on paper.

Chapter 2 in the anthology is György Ránki's “'Unwilling Satellite' or 'Last Satellite': Some Problems of Hungarian-German Relations." Written in 1982, this article was published in 
Pastor, Peter. "A New Historical Myth from Hungary: The Legend of Colonel Ferenc Koszorús as the Wartime Savior of the Jews of Budapest. Review Article of Jeszenszky, Géza, ed. July 1944: Deportation of the Jews of Budapest Foiled. Reno, Nevada: Helena History Press, 2018, pp. 317. Distributed by CEU Press." Hungarian Cultural Studies. e-Journal of the American Hungarian Educators Association, Volume 12 (2019) DOI: 10.5195/ahea.2019.355

1983 in Hungarian and in 1984 in English. During the eighties Ránki was the director of the Institute of History of the Academy of Sciences in Budapest and the first occupant of the Hungarian Chair at Indiana University. Ránki died in 1988 at the age of 58. His essay is thirtyseven years old; one wonders, had Ránki lived past the 1989 regime change, would he not have revised his essay? It is also doubtful that he would have offered the article to Jeszenszky for the purpose of spreading the myth about Colonel Koszorús in the English-speaking world. Ránki's essay is the only one in the anthology that contains, alongside the original footnotes, updated ones with recent sources. Jeszenszky also inserted footnotes as editor's notes in which he takes issue with the dead Ránki. The place for these criticisms should have been in the Introduction. Though Jeszenszky identifies the article as a "summary of Hungary's conduct during the Second World War" (32), in fact it deals with Hungarian-German relations from 1933 to the occupation in 1944, and there is not one word in it about the Koszorús Action.

Ránki's essay goes back to the early 1930s and traces Hungary's evolution from having a largely independent foreign policy to a policy increasingly dependent on Germany. In his work, Ránki offers a paradigm consisting of stages representing degrees of change. He identifies the first stage, 1933 to 1938, with the economic penetration of Hungary by the Third Reich and the loss of Hungary's ability to act as a sovereign state. Ránki believed that the success of Germany in drawing Hungary into its sphere of influence was also due to the fact that both countries possessed regimes that "were anti-liberal, anti-democratic, only Germany was Fascist, but Hungary authoritarian” (39). Ránki's characterization of the Hungarian system is significant, as it indicates that by the early eighties Hungarian historians no longer characterized the Horthy regime as Fascist.

Ránki identifies his second stage, 1938 to1941 with Hungarian territorial revisionism, which was the driving force of internal and external policy and had been carried out to considerable success with active German involvement. During this period Hungary still tried "to maintain a relatively independent foreign policy course," which was, "coupled with the intention of continuing to go along with Hitler as far as revision was concerned." Ránki characterizes this period as a time during which Hungary was "still trying to keep two irons in the fire" (49). It was "putting Hungary in a kind of (willing and unwilling) satellite position" as well (50).

The third stage is the period between 1942 and 1944, essentially the era of the prime ministry of Miklós Kállay. Ránki notes that under Kállay, "Hungary was the first satellite to look for a way out after the hopes of German victory faded." Hungary therefore became the unwilling satellite, but it was unsuccessful in its effort to separate itself from Germany (53). While Ránki describes Hungary as an unwilling satellite, he tempers his observation when he states that "even during this period "German-Hungarian relations were based on German interest" (59). This was due to Germany's successful manipulation of the frontier issue. The author points out that it is for this reason that between November 1943 and February 1944 Hungary retreated from its preliminary armistice deal of September with the British. It feared losing the recovered Northern Transylvania to Romania as, "Hungary was promised no territorial reward in case of disalignment" (61). Ránki's description indicates that although feelers were put out for peace, Hungary was not ready to drop out of the war because it was constrained by the territorial issue (61). Viewed this way, Hungary was a sulking but stable ally, rather than a reluctant one. In this respect, it is noteworthy that the author claims that even before the German occupation of March 
Pastor, Peter. "A New Historical Myth from Hungary: The Legend of Colonel Ferenc Koszorús as the Wartime Savior of the Jews of Budapest. Review Article of Jeszenszky, Géza, ed. July 1944: Deportation of the Jews of Budapest Foiled. Reno, Nevada: Helena History Press, 2018, pp. 317. Distributed by CEU Press." Hungarian Cultural Studies. e-Journal of the American Hungarian Educators Association, Volume 12 (2019) DOI: 10.5195/ahea.2019.355

19, 1944, Hungary, "was already on the road to becoming the last to stay in the Axis camp" (63). From Ránki's article, one can see that the German occupation was not the clear milestone that ended Hungary's role as the unwilling satellite. Hungary toed the German line even before that.

Chapter 3 contains Jeszenszky's second essay, "Hungary in the Second World War:

Tragic Blunders or Destiny." It is, according to the author, a "modified and expanded version" of an essay that was first published in 2014. Jeszenszky, who has earlier demonstrated that he is fond of posing questions (7-9, 23-24), repeats this approach, in the title as well as in the article (68). Unfortunately, he does not always reply to these questions; or at best, he offers vague answers with an "on the other hand" provision that indicates equivocation. To provide historical background for his article, Jeszenszky goes back to the Peace Treaty of Trianon of 1920, which he identifies as the source of all problems. Hungary lost substantial territory and millions of Hungarians found themselves on the other side of the "unfair" borders drawn by the Paris Peace Conference of 1919. The treaty was denounced by most Hungarians.

Although the League of Nations Covenant included articles allowing the revision of treaties, the successor states refused to give up an inch of disputed territory. Jeszenszky therefore finds it "unreasonable to blame Hungary for advocating peaceful territorial revision throughout the interwar period.... The craving to revise the treaty peacefully was the leitmotif of Hungary's foreign policy" (69). Historical facts, however, contradict his claim of peaceful revision. The first example that comes to mind was the armed fighting in the Burgenland, which in the peace treaty had been ceded to Austria. During the fall of 1921, the para-military detachments of Pál Prónay and Iván Héjjas, operating with the consent of the Hungarian government, clashed with the Austrian forces. The conflict was resolved by the Sopron plebiscite of December 1921, which was decided in favor of Hungary (Juhász 1979: 62-63). On October 31, 1938, the former prime minister, István Bethlen, best expressed the Horthy regime's revisionist territorial demands on Czechoslovakia when he declared: "We are determined that the question be resolved once and for all!...if possible peacefully, if not, by force!" [El vagyunk határozva, hogy ezt a kérdést véglegesen megoldjuk!...ha lehet békés eszközökkel, s ha nem, akkor erövel!] (Janek 2014: 177).

Soon afterward, the First Vienna Award of November 2, 1938, arbitrated by Fascist Italy and Nazi Germany, forced Czechoslovakia to cede peacefully most of the Hungarian inhabited part of Slovakia including a small segment of the Subcarpathian region. Jeszenszky explains that a day after Slovakia declared independence on March 14, 1939, Hungary occupied the rest of Subcarpathia, a step which was accepted by Hitler. In fact, the chronology is the reverse. It was Hitler, who permitted the Hungarians to occupy Subcarpathia, giving them a twenty-four hour window to do it. Jeszenszky also fails to mention that the speedy occupation was followed by the so-called "little-war," military clashes between the Slovak and Hungarian armed forces for the possession of the area, which lasted for three days, from March 23 to March 25, with fatalities on both sides and was decided in favor of the Hungarians (Janek 2014: 173). It is evident that peaceful resolution of revisionism, as claimed by Jeszenszky, was not the only option for Hungary.

Jeszenszky writes that "It has become customary to say that becoming a satellite of Nazi Germany was Hungary's inevitable destiny, a course predetermined by the Trianon Treaty and the desire to revise its terms" (73). He provides no reference as to the identity of the scholarly 
Pastor, Peter. "A New Historical Myth from Hungary: The Legend of Colonel Ferenc Koszorús as the Wartime Savior of the Jews of Budapest. Review Article of Jeszenszky, Géza, ed. July 1944: Deportation of the Jews of Budapest Foiled. Reno, Nevada: Helena History Press, 2018, pp. 317. Distributed by CEU Press." Hungarian Cultural Studies. e-Journal of the American Hungarian Educators Association, Volume 12 (2019) DOI: 10.5195/ahea.2019.355

"sayers." He, however, blames the Munich Conference of 1938 for leaving Central Europe "to the mercy of Germany" (69). He offers victimhood history, blaming Britain and France for Hungary's drift into Germany's orbit, thereby rejecting the determinist thesis. Instead, by offering a quote from George Kennan (74), he explains that after it was assigned to the German sphere of influence by the West, Hungary chose limited collaboration instead of suicidal resistance which would have weakened the opposition forces. These forces then would make Hungary in 1943 into an "unwilling satellite." Jeszenszky believes that under the circumstances, Hungary made the right choice. This interpretation sees Hungary as a victim and fits into the prevailing official master narrative.

For Jeszenszky the blunders made by the Hungarian government leaders came with the war. The first was when with Germany, Hungary attacked Yugoslavia in April1941 in an effort to recover a part of historic Hungary. This was followed by Hungary's attack on the Soviet Union on June 27, 1941, five days after the seemingly successful German invasion. While he condemns Hungary's war against the USSR, he offers extenuating circumstances for Hungary's decision: the German domination of the continent, Russia's poor military showing in the RussoFinish winter war [which did not take place in 1938, but from November 30, 1939 to March 13, 1940] (80), and concern that with Slovakia and Romania on the Germany's side, Hungary would lose territories it had recently regained with German help. He seems to share Prime Minister László Bárdossy's view that at that point Hungary "had no real choice" (81), that it was part of Hungary's destiny.

In fact, Jeszenszky's list demonstrates that the Hungarian leaders failed to consider evidence that should have prompted them to stay out of the war, given that Germany did not call on Hungary to join the war against the USSR. Evidently Hungarian decision-makers failed to consider that Germany had already lost the "Battle of Britain." Instead of the Soviet fiasco in Finland, they should have paid attention to General Georgy Zhukov's impressive victory against the Japanese in Central Asia in August 1939. Lastly, the Hungarian political establishment was familiar with Professor Iván Lajos's popular Szürkekönyv ['Grey Book'] that was published in 1939 and was printed in 39,000 copies. The pamphlet-sized essay concluded that Germany could not win a multi-front war (Pritz 2011: 121-122), yet it failed to inspire Hungary's leaders to keep Hungary out of the war as long as possible.

Following the defeat of the German army under Moscow in December 1941 and with the US in the war, Jeszenszky explains that Horthy began to have doubts about a German victory and for this reason appointed Miklós Kállay prime minister to orchestrate Hungary's switching sides and leaving the war. This, however, was not possible, as "having joined the war, Hungary was indeed on a set course, no longer a master of its fate" (85). The blunder committed on June 27, 1941 became Hungary's destiny as it was unable to extricate itself from its alliance with Germany and from the war. In spite of his negative assessment of Kállay's endeavors, Jeszenszky spends the rest of the paper on the various unsuccessful peace feelers the Hungarian prime minister launched. In the process, Jeszenszky recognizes that the Allied policy of unconditional surrender of the Axis forces also limited the chances of Hungarian peace attempts that were unrealistically conditioned on the retention of some of the recovered territories. 
Pastor, Peter. "A New Historical Myth from Hungary: The Legend of Colonel Ferenc Koszorús as the Wartime Savior of the Jews of Budapest. Review Article of Jeszenszky, Géza, ed. July 1944: Deportation of the Jews of Budapest Foiled. Reno, Nevada: Helena History Press, 2018, pp. 317. Distributed by CEU Press." Hungarian Cultural Studies. e-Journal of the American Hungarian Educators Association, Volume 12 (2019) DOI: 10.5195/ahea.2019.355

Jeszenszky declares that, "Today most historians admit that the demand for unconditional surrender was a most serious mistake which considerably extended the duration of the war" (89). In fact, this new policy assured Stalin that the western Allies would not make separate peace with the Germans. (Mastny 1979: 145). Jeszenszky argues that unconditional surrender shattered the German generals' plan to carry out a conspiracy in 1943 to overthrow Hitler. It is unclear why Jeszenszky assumes that a plot in 1943, when Nazi victory was still in sight, would have succeeded, given that the generals' conspiracy in July 1944, when Germany was on the ropes, was a spectacular failure.

Concluding his analysis Jeszenszky notes that Kállay, "was strongly opposed to the Nazi ideology" and "his diplomatic efforts to break away from Germany were not amateurish." Also, "he was opposite of an anti-Semitic" $[$ sic $]$ and was "sincere in his determination to protect the Jewish citizens of Hungary" (96-97). While it is true that he disdained Nazi ideology, and was no amateur when it came to diplomacy, he was no philosemite. It is to his credit that he resisted German demands to "solve the Jewish question," but as was pointed out by András Joó, he did this not out of humanitarian concerns, but because he thought that such a policy would provide a positive image of Hungary in the eyes of the Western Allies (Joó 2008: 117, 124). Furthermore, it was under Kallay's prime ministry that the so-called Fourth Jewish law was introduced in September 1942. The law confiscated Jewish owned agricultural lands and woodlands, which were then redistributed among non-Jews. His action further undermined Jewish economic existence (Pritz 2011: 146). It also sensitized most of the non-Jewish Hungarian population to be receptive to the deportations in 1944 as this permitted them to share in the pillaging of the assets of the Jewish victims (Joó 2008: 134-135). Had Jeszenszky not ignored this Jewish law of Kállay, he could have seen the Prime Minister's Jewish law as another tragic blunder. Concluding his examination of Kállay's premiership, Jeszenszky considers the second biggest blunder of the war to be the failure of Kállay to prepare the army for resistance against an impending German invasion (98). The essay ends with the lesson of the "final blunder," which is "the death of traditional Hungary" (101). As to why that would be a lesson instead of the consequence of the whole series of blunders examined by Jeszenszky is a mystery. While Jeszenszky grieves for the old regime, at the end of the war the majority of the Hungarians saw its demise in a salutary light.

Chapter Four contains Deborah Cornelius's contribution. In the table of contents, the essay is entitled "From Occupation to Koszorús's Action," but on the article's title page and on the running heads is identified as "Road to Occupation." The title in the table of contents is nearer to Cornelius's focus, as her paper concentrates on Regent Horthy and the fate of the Hungarian Jews from the start of the German occupation on March 1944 until mid-August, 1944. The confusion in the titles may have been caused by the fact that Jeszenszky culled the article from various pages of Cornelius's 2011 monograph, Hungary in World War II: Caught in the Cauldron (Cornelius 2011). Contrary to Jeszenszky's high esteem of the book, it was strongly criticized by reviewers both in the US and Hungary as a work that rehabilitates the Horthy regime and falsifies history (Berend 2012, Deák 2013, Pastor 2012, Csősz 2013). For this very reason, however, the book was translated into Hungarian (Cornelius 2015) and became the master narrative favored by the Orbán regime and its Veritas Historical Institute headed by Sándor Szakály (Pastor 2016, Veritas Történetkutató Intézet 2015). 
Pastor, Peter. "A New Historical Myth from Hungary: The Legend of Colonel Ferenc Koszorús as the Wartime Savior of the Jews of Budapest. Review Article of Jeszenszky, Géza, ed. July 1944: Deportation of the Jews of Budapest Foiled. Reno, Nevada: Helena History Press, 2018, pp. 317. Distributed by CEU Press." Hungarian Cultural Studies. e-Journal of the American Hungarian Educators Association, Volume 12 (2019) DOI: 10.5195/ahea.2019.355

Cornelius claims that with the German occupation Hungary lost its sovereignty, therefore responsibility for whatever happened in Hungary from March 19, 1944, until the end of the war could be shifted to Nazi Germany. Thus, Cornelius could insist that a German shadow government ruled Hungary (137). However, as a number of historians have noted, Germany did not have, nor did it wish to have absolute control over Horthy's Hungary. The diplomatic historian, the late Gyula Juhász, noted that the occupiers arrested only a relatively few from the state apparatus, and the establishment, and encouraged the regent to remain at his post, name a new government while institutions of the regime continued to function undisturbed. In Hungary only the Jews as a group had to fear the occupation, and they suffered a dual threat-the German occupying organs and the Hungarian administration (Juhász 1986: 146-147). The Germans did pressure Hungary to deport the Jews, but as István Deák noted in his recent book, “Germany's allies were independent enough to decide how far they would go in cooperating with the Nazis in the so-called Final Solution of the Jewish Question" (Deák 2015: 86). Incredibly, Cornelius blames the US Department of State and the British Foreign Office for suppressing the information about the extermination camps, thereby implying that Horthy and the others had been kept in the dark (145). She also faults the Hungarian Jewish leaders for not preparing their people for resistance, as if the Hungarian community around them did not deny them moral support and the military the guns.

The Cornelius selection ends with the retelling of the Koszorús Action and its immediate aftermath. For Cornelius it was Colonel Koszorús, conveying Horthy's command, who ordered Baky and his men out of the city. According to Cornelius, Koszorús also had to consider armed German interference. The Gestapo units consisted of "only three battalions in the capital, motorized with excellent weapons, but Koszorús commanded a larger force" (153). The tale of well-armed German police units is contradicted by Koszorús in his memoirs, even though Cornelius cites the memoirs to back her claim. Koszorús minimized the potential threat coming from the three Gestapo units as they were equipped "only with light weapons and trucks for transport" [csak könnyü fegyverzettel és gépkocsi-szállítással] (Koszorús 1987: 59). By misrepresenting the Koszorús account, Cornelius seems intent on portraying the Germans as a powerful force in the drama and adds a new twist to the story. She maintains that on June 7 and 8 a crisis atmosphere existed in the city because of the "rumors of imminent entry of German military units" (153). She does not address the rumor's veracity, or lack thereof. The real rumor, as indicated earlier, was the illusory Baky coup, a coup the state secretary and his gendarmes never had contemplated. The story ends in mid-August 1944, but there is no mention that it was then that Horthy approved the plan for the resumption of deportations that were to start on August 25. The plan was abandoned on the $23^{\text {rd }}$ when Romania switched from the Axis to the Allied side (Ránki1968: 897-898).

Chapter Five is István Deák's essay, "Holocaust in Hungary," which was originally published in 2004. This means that since then its author may have changed or refined his view about the Koszorús Action. In the essay, we are correctly told that, following the German occupation of Hungary on March 19, 1944, Horthy left all Jewish matters in the hands of the prime minister, Döme Sztójay, his cabinet, and his administration. The deportation started on May 15, 1944, and in less than two months 450,000 Jews from the provinces were sent to Auschwitz-Birkenau. "Deeply impressed by Allied successes in Normandy, Horthy on July 7 
Pastor, Peter. "A New Historical Myth from Hungary: The Legend of Colonel Ferenc Koszorús as the Wartime Savior of the Jews of Budapest. Review Article of Jeszenszky, Géza, ed. July 1944: Deportation of the Jews of Budapest Foiled. Reno, Nevada: Helena History Press, 2018, pp. 317. Distributed by CEU Press." Hungarian Cultural Studies. e-Journal of the American Hungarian Educators Association, Volume 12 (2019) DOI: 10.5195/ahea.2019.355

[correct date, July 6], 1944, forbade further deportations." The order came a few days after gendarmes arrived to Budapest to begin deportations. Horthy was persuaded by his friends that these men and far right politicians were planning a coup against him and he ordered an armored unit to Budapest. Deák notes that Horthy's decision to order military forces to prevent the deportation of Jews was "unique in the history of the Holocaust" (176-177). The problem with this conclusion is that it contradicts Professor Deák's own claim made a paragraph before, that the troops were ordered to the capital to help Horthy retain power and not to save the Jews of Budapest (177). Moreover, according to another Deák article, published in 2003 in The New York Review of Books, and extensively quoted by Jeszenszky, it was primarily Horthy's "considerable prestige" and not the threat of force that seemed to be the major reason why the gendarmes withdrew from the city (27). Were Koszorús and his troops in the business of saving Jews, they would have mobilized to save the 24,000 Jews in the immediate periphery of Budapest, who between July 6 and 8 were deported by the gendarmes (Molnár 2014). In both the Deák quote in Jeszenszky's Introduction and in the Deák article, Colonel Koszorús is not mentioned by name. This may indicate that in Deák's opinion Koszorús does not merit special recognition as he merely carried out a military order that came directly from the Supreme Warlord Miklós Horthy.

The sixth chapter is Tamás Stark's 2007 essay, "Facts about the Number of Shoah Victims in Hungary." It deals with the problem of arriving at a precise number of victims and survivors of the Shoah. Stark observes, "The difficulties due to the lack of data supply are capped by decades of uncertainty regarding the statistical census of the Jewish population" (187). Its direct relevance for the anthology is one statistic: "there were 231,453 Jews living in Budapest when the German troops marched in" (190), and not 300,000 as Jeszenszky claims (8), perhaps on the basis of Koszorús (Koszorús 1987: 62).

Chapter Seven is an essay Jeszenszky has selected, without identifying the source, from Páncélosokkal az életért (Hantó and Szekér 2015: 28-40). "The Role of Colonel F. Koszorús in the Prevention of the Deportations of the Jews of Budapest," also glorifies Colonel Koszorús's deeds. This essay is by Attila Bonhardt, the director of the Military History Archives. It selectively follows the Koszorús memoirs in enumerating the colonel's activities during the socalled Baky putch and emphasizes that both Regent Horthy and Colonel Koszorús were out to save the lives of the Jews of Budapest. In order to prove his claim, Bonhardt's inaccurate detailing of the facts relate to his description of Koszorús's June 5, 1944, meeting with Horthy, which cites Koszorús's memoir as the source. According to Bonhardt, on June 5 "Horthy informed him [Koszorús] in Lázár's presence that Baky and his circle wanted to begin the deportations of the Jews of Budapest on 6 July. He gave them the order by word of mouth to expel the gendarmerie battalions from the city..." (214). In fact, what Koszorús wrote was that Horthy ordered him to prevent the alleged coup (Koszorús 1987: 60) and not to preempt the deportation of the Budapest Jews by Baky and his men. It seems that Bonhardt twisted Koszorús's story in order to show that saving the Jews was Horthy's and Koszorús's primary preoccupation during those crucial days. Bonhardt overlooks, however, that from July 6 to July 8 Koszorús and his tankmen, stationed in full alert in the outskirt locale of Óbuda, had stood by, doing nothing, while the deportation of Jews was taking place right in full view by Baky's gendarmes. 
Pastor, Peter. "A New Historical Myth from Hungary: The Legend of Colonel Ferenc Koszorús as the Wartime Savior of the Jews of Budapest. Review Article of Jeszenszky, Géza, ed. July 1944: Deportation of the Jews of Budapest Foiled. Reno, Nevada: Helena History Press, 2018, pp. 317. Distributed by CEU Press." Hungarian Cultural Studies. e-Journal of the American Hungarian Educators Association, Volume 12 (2019) DOI: 10.5195/ahea.2019.355

Chapter Eight is an expanded article that was published on the Internet in 2012 by Susan Berger and Vadim Bernstein under the title, "Raoul Wallenberg-Not an Accidental Choice for Hungary in 1944." Wallenberg arrived in Budapest on July 9, 1944, three days after Horthy suspended the deportations of Budapest Jews. In a book dealing mainly with the survival of the Budapest Jews, one would have expected the selection of an essay that examined the last five months of the regency of Horthy and the Arrow Cross dictatorship of Szálasi when the Swedish diplomat, as noted by Jeszenszky (9), saved the lives of thousands of Jews in Budapest. Instead, we only learn about some of the precedents taking place in Sweden (albeit perhaps not the most important ones) before Wallenberg embarked on his diplomatic mission. The format of this essay is different from the others, as it includes a three-and-a-half-page Selected Bibliography and seems to have no real direct bearing on the main issues discussed in the book.

It is a mystery why a historian would include in his anthology Koszorús Jr.'s subjective and uncritical essay, "Colonel Ferenc Koszorús Witness and Paragon," instead of a selection from Koszorús Sr.'s own memoir as Chapter Nine. This article was also selected from Páncélosokkal az életért (Hantó and Szekér 2015: 19-27). In his son's essay, the Baky putsch was a planned "lightning strike" against the Budapest Jews, but Koszorús intervened militarily and "saved countless lives." Koszorús Jr. claims that the "operation known as the Koszorús Action," was a singular initiative on the part his late father for which he took no credit (250), that the putsch collapsed thanks to the Koszorús Action, and that "this conclusion is supported by survivors, participants, witnesses, documents and objective historians" (260-261). Koszorús Jr. claims that his father's heroism was ignored by historians during the Rákosi and Kádár regimes (251). Why would they have ignored Colonel Koszorús's alleged attempt to save the Jews while Major-General Vilmos Nagybaczoni Nagy, Horthy's Minister of War between September 1942 and June 1943, received full accolades in communist era history books for trying to alleviate the treatment of Jewish labor service troops (Ránki1976: 1085, Nagybaczoni Nagy 1986)?

The essays of the collection cover a broader period than the book's title and Jeszenszky's intended goal indicates. The contents of the volume are not limited to July 1944, as the articles touch on Hungary's role in World War II, Hungarian-German relations, Horthy's leadership, and the fate of Hungary's Jewish citizens. Unfortunately, Jeszenszky failed to put together a balanced selection of readings for English speakers. When it comes to July 1944, several of the essays, including one of Jeszenszky's, construct the legend of Colonel FerencKoszorús's heroism in allegedly saving the 300,000 Jews of Budapest. Perhaps there is a societal need to find heroes in a country that fought on the wrong side and from which close to a half a million Jews were sent to death camps in the waning months of the war. Creating myths, however, that can only be achieved by falsifying history, should not be the role of historians. Both of Jeszenszky's chapters, as well as some others in this anthology, twist the facts to a greater or lesser extent in order to fortify the various themes. The authors of these previously published articles, in the words of the much-referenced Randolph Braham, whitewash Hungarian history as related to the Holocaust and try to rehabilitate Miklós Horthy and his regime. It seems that they were selected for republication for that very reason. The inclusion of essays from Ránki, Deák, and Stark, on the other hand, may have been motivated by giving respectability to an anthology that otherwise does not meet the academic minimum. 
Pastor, Peter. "A New Historical Myth from Hungary: The Legend of Colonel Ferenc Koszorús as the

Wartime Savior of the Jews of Budapest. Review Article of Jeszenszky, Géza, ed. July 1944: Deportation of the Jews of Budapest Foiled. Reno, Nevada: Helena History Press, 2018, pp. 317. Distributed by CEU Press." Hungarian Cultural Studies. e-Journal of the American Hungarian Educators Association, Volume 12 (2019) DOI: 10.5195/ahea.2019.355

\section{Works Cited}

Berend, Iván T. 2012. "Hungary in World War II: Caught in the Cauldron.” Slavic Review 71. 3:678-679.

Bihari, Péter. 2018. "Az antiszemitizmus magyar hagyománya" ['The Hungarian Tradition of Hungarian Anti-Semitism']. Élet és Irodalom 62. 46: Nov. 16. https://www.es.hu/cikk/2018-11-16/bihari-peter/az-antiszemitizmus-magyarhagyomanya.html

Braham, Randolph L. 2016. "Hungary: The Assault on the Historical Memory of the Holocaust." In The Holocaust in Hungary: Seventy Years Later. Ed. Randolph L. Braham, and András Kovács. Budapest: Central European University Jewish Studies Program. 261-309.

Csepeli, György and Vági, Zoltán. 2011. "Adolf Eichmann személytelen személyisége" ['Adolf Eichmann's Impersonal Personality']. Mozgó Világ 37. 6: 36-46. http://epa.oszk.hu/01300/01326/00128/MV_EPA01326_2011_06_01_4.htm

Csepeli, György. 2016. A meg nem gondolt gondolat. A zsidó ellenességtöl a népirtásig ['The Thoughtless Thought: From Anti-Semitism to Genocide']. Budapest: Kossuth.

Csősz, László. 2013. "Konzervált Mitoszok” [Preserved Myths]. BUKSZ 25. 1: 36-42. Buksz.c3/hu1301/03biralat.pdf.

Csunderlik, Péter. 2019. A “Vörös Farsangtól” a "Vörös Tatárjárásig”: A Tanácsköztársaság a korai Horthy-korszak pamflet- és Visszaemlékezés-irodalomban [From the "Red Carnival" to the "Red Mongol Invasion": The Hungarian Soviet Republic in the Pamphlet and Memoir Literature of the Early Horthy Era]. Budapest: Napvilág Kiadó.

Cornelius, Deborah S. 2011. Hungary in World War II: Caught in the Cauldron. New York: Fordham UP.

Cornelius, Deborah S. 2015. Kutyaszorítóban: Magyarország és a II. világháború [Hungary in World War II. Caught in the Cauldron]. Budapest. Rubicon-Könyvek.

Deák, István. 2015. Europe on Trial: The Story of Collaboration, Resistance, and Retribution during World War II. Philadelphia: Westview Press-Persus Books.

Deák, István. 2013. "Hungary in World War II: Caught in the Cauldron." Holocaust and Genocide Studies 27. 3: 500-502.

Gellért, Ádám and Dávid Turbucz. 2012. "Egy elmaradt felelősségre vonás margójára: Horthy Miklós Nürnbergben" ['Marginal Notes to a Missed Trial for Accountability: Miklós Horthy in Nuremberg']. Betekintö. 4:

1-20.http://www.betekinto.hu/sites/default/files/betekinto-szamok/2012_4_gellert_turbucz.pdf

Hantó, Zsuzsa and Nóra Szekér, eds. 2015. Páncélosokkal az életért: "Koszorús Ferenc a holokauszt höse" ['With Tanks for Life: "Ferenc Koszorús the Hero of the Holocaust"،]. Budapest: Koszorús Ferenc Emlékbizottság.

Horthy, Miklós. 1990. Emlékirataim [My Memoirs]. Budapest: Európa

Janek, István. 2014. "A szlovák-magyar "kis háború” története és annak interpretációi a nemzeti történetirásokban" ['The History of the Slovakian-Hungarian "Little War" and its Interpretation in National Historiographies']. In Kárpáti Ukrajna. Vereckétöl Husztig. Egy konfliktustörténet nemzeti olvasatai. ['Carpathian Ukraine. From the Veretsky Pass to Khust. The national interpretations of a history of conflict']. Ed. Csilla Fedinec. Bratislava: Kalligram. 173-194. 
Pastor, Peter. "A New Historical Myth from Hungary: The Legend of Colonel Ferenc Koszorús as the Wartime Savior of the Jews of Budapest. Review Article of Jeszenszky, Géza, ed. July 1944: Deportation of the Jews of Budapest Foiled. Reno, Nevada: Helena History Press, 2018, pp. 317. Distributed by CEU Press." Hungarian Cultural Studies. e-Journal of the American Hungarian Educators Association, Volume 12 (2019) DOI: 10.5195/ahea.2019.355

Jeszenszky, Géza. 2018. "Horthy és a magyar zsidók deportálása” ['Horthy and the Deportation of the Hungarian Jews']. Magyar Szemle új folyam 27. 1-2.

http://www.magyarszemle.hu/cikk/20180302_horthy_es_a_magyar_zsidok_deportalasa

Joó, András. 2008. Kállai Miklós külpolitikája: Magyarország és a háborús diplomácia 1942-1944 ['The Foreign Policy of Miklós Kállay. Hungary and Wartime Diplomacy 1942-1944’]. Budapest: Napvilág Kiadó.

Juhász, Gyula, 1986. A háború és Magyarország 1938-1945 ['The War and Hungary 1938-1945']. Budapest: Akadémiai Kiadó.

Juhász, Gyula. 1979. Hungarian Foreign Policy 1919-1945. Budapest: Akadémiai Kiadó.

Karady, Victor. 2016. “Continuities of the 'Jewish Question' in Hungary since the 'Golden Age'.” In The Holocaust in Hungary: Seventy Years Later. Ed. Randolph L. Braham and András Kovács. Budapest: Central European University Jewish Studies Program. 45-72.

Karsai, Elek, ed. 2017. Vádirat a nácizmus ellen: Dokumentumok a magyarországi zsidóüldözés történetéhez ['Indictment against Nazism. Documents on the History of the Persecution of Jews in Hungary']. Vol. 3. 1944. Június 26.-1944. október 15. A budapesti zsidóság deportálásának felfüggesztése ['June 26, 1944-October 15, 1944. The Suspension of the Deportation of the Jews of Budapest']. Budapest : Balassi Kiadó. http://www.balassikiado.hu/BB/NET/Vadirat_3jav.pdf

Karsai, László, 2005. “A magyarországi zsidótörvények és rendeletek, 1920-1944” ['The Jewish Laws and Decrees in Hungary, 1920-1944']. In A holokauszt Magyarországon európai perspektívában ['The Holocaust in Hungary in a European Perspective']. Ed. Judit Molnár. Budapest: Balassi Kiadó. 140-163.

http://hdke.hu/files/csatolmanyok/09_KarsaiLaszlo_AMagyarorszagi_zsidotorvenyek.pdf

Karsai, László. 2012. "Érvek a Horthy-szobor mellett” ['Arguments in Support of a Horthy Statue']. Mozgó Világ, nos. 8-9, 45-60.

Karsai, László. 2014. "Koszorús és a pesti zsidók” ['Koszorús and the Jews of Budapest']. Népszabadság, June 8. nol/hu/velemeny/koszorus-es-a-pesti-zsidok-1472857

Kovács, András. 2016. "Hungarian Intentionalism: New Directions in the Historiography of the Hungarian Holocaust.” In The Holocaust in Hungary. Seventy Years Later. Ed. Randolph L. Braham, and András Kovács. Budapest: Central European University Jewish Studies Program. 3-24.

Kovács, M. Mária. 2012. Törvénytöl sújtva: A numerus clausus Magyarországon, 1920-1945 ['Punished by the Law: The Numerus Clausus in Hungary, 1920-1945']. Budapest: Napvilág Kiadó.

Koszorús, Ferenc. 1987. Emlékiaratai és tanulmányainak gyüjteménye ['Memoirs and Collection of His Essays']. Englewood, NJ: Universe Publishing Company.

Mastny, Vojtech. 1979. Russia's Road to the Cold War. Diplomacy, Warfare and the Politics of Communism, 1941-1945. New York: Columbia UP.

Molnár, Judit. 2014. "Merjünk nagyot csúsztatni" ['Dare to Tell a Big Lie']. Élet és Irodalom 58. 3: January 17. https://www.es.hu/cikk/2014-01.../merjunk-nagyot-csusztatni.html Nagybaczoni Nagy,Vilmos. 1986. Végzetes esztendők ['Fateful Years']. Budapest: Gondolat. 
Pastor, Peter. "A New Historical Myth from Hungary: The Legend of Colonel Ferenc Koszorús as the

Wartime Savior of the Jews of Budapest. Review Article of Jeszenszky, Géza, ed. July 1944: Deportation of the Jews of Budapest Foiled. Reno, Nevada: Helena History Press, 2018, pp. 317. Distributed by CEU Press." Hungarian Cultural Studies. e-Journal of the American Hungarian Educators Association, Volume 12 (2019) DOI: 10.5195/ahea.2019.355

Pastor, Peter. 2012. "Inventing Historical Myths.” Hungarian Cultural Studies 5, 1- 29. https://ahea.pitt.edu/ojs/index.php/ahea/article/viewFile/82/71.

Pastor, Peter. 2016. "Történelmi mitoszok újragyártása” [The Remanufacturing of Historical Myths]. Századok 150. 6: 1563-1584.

Pritz, Pál. 2011. "Lajos Iván és a magyar külpolitikai gondolkodás” ['Iván Lajos and Hungarian Foreign Political Thought']. In Az objektivitás mitosza? ['The Myth of Objectivity?']. Budapest: Magyar Történelmi Társulat. 109-122

Püski, Levente. 2015. A Horthy-korszak parlamentje ['The Parliament of the Horthy Era']. Budapest: Országgyülés Hivatala.

Ránki, György.1988a. "A németek szerepe a magyarzsidók elpusztításában" ['The Role of the Germans in the Destruction of the Hungarian Jews']. In A Harmadik Birodalom árnyékában. ['In the Shadow of the Third Reich']. Budapest: Magvető Kiadó. 211-231.

Ránki, György.1964. Emlékiratok és a valóság Magyarország második világháborús szerepéröl ['Memoirs and the Truth about the Role of Hungary in World War II']. Budapest: Kossuth Könyvkiadó.

Ránki, György.1988b. “Magyar Holocaust.” In A Harmadik Birodalom árnyékában ['In the Shadow of the Third Reich']. Budapest: Magvető Kiadó. 195-210.

Ránki, György, ed.1968. A Wilhelmstrasse és Magyarország. Német diplomáciai iratok Magyarországról 1933-1944 ['The Wilhelmstrasse and Hungary. German Diplomatic Documents about Hungary 1933-1944']. Budapest: Kossuth Könyvkiadó.

Ránki, György, ed. 1976. Magyarország Története 1918-1919 1919-1945 ['The History of Hungary1918-1919 1919-1945']. Budapest: Akadémiai Kiadó.

Szinai, Miklós and Szücs, László, eds. 1972. Horthy Miklós titkos iratai ['The Confidential Papers of Miklós Horthy']. Budapest: Kossuth Könyvkiadó.

Török, Bálint. 2018. "A Magyar Függetlenségi Mozgalom zsidómentő tevékenysége 1. Rész” ['The Activities of the Hungarian Independence Movement in Saving Jewish Lives']. Magyar Szemle új folyam 27.11-12.

Turbucz, Dávid. 2011. Horthy Mikló, Budapest: Napvilág Kiadó.

Ungváry, Krisztián. 2016."Master Plan? The Decision-Making Process behind the Deportations." In The Holocaust in Hungary. Seventy Years Later. Ed. Randolph L.Braham, and András Kovács. Budapest: Central European University Jewish Studies Program. 105-146.

Vági, Zoltán, Csősz, László and Kádár, Gábor. 2013. The Holocaust in Hungary: Evolution of a Genocide. Lanham, MD: AltaMira Press.

Veritas Történetkutató Intézet. 2015. “Amerikai történész könyve Magyarország második világháborús dilemmáiról” ['A Book by an American Historian about the Dilemas of World War II'] Sajtómegjelenések Archivuma. Budapest: July 7. http://veritasintezet.hu/images/sajto_archivum/2015_07_07_MTI_Kutyaszoritoban.pdf

Vértes, Robert, ed. 1997. Magyarországi zsidótörvények és rendeletek 1938-1945 ['Hungarian Jewish Laws and Decrees 1938-1945’]. Budapest: Polgár. 